\title{
The Erasmian Ideal of Kingship, as reflected in the work of Ronsard and d'Aubigné
}

\author{
GWENDA ECHARD
}

In his treatise Institutio principis Christiani, written in 1516, Erasmus elaborated his conception of a Christian monarch who lived and moved within a network of mutual obligations, supporting his subjects and being supported by them, answerable for his kingly charge to God himself. The ideas are not in themselves original, but they are voiced with a combination of felicitous expression and moral indignation that is unique to Erasmus and gives him his authority. That authority was to prove so durable, on a philosophical if not a practical level, that the Erasmian ideal of kingship would be echoed over the next century in the work of two poets as different as Ronsard and d'Aubigné. This ideal, its imagery, and the way in which they reappear, with variations, in the work of these poets, merit an examination.

Erasmus' particular view of kingship is, of course, a blend of the classical and the Christian. In classical terms he is clearly in the Platonic tradition of the philosopher king. The concept of the learned monarch, of the king who is good as well as wise, is a classical one, as are the notions of the king as the earthly counterpart of God in His universe or of the king as a prophet of God. In the Institutio Erasmus expresses these ideas in images, some of which go back to Isocrates and all of which became common currency in the Renaissance. ${ }^{1}$ There is animal imagery - the king as lion, as eagle; there are images related to the elements - water for example; there is imagery of a cosmic nature, including the all-pervasive imagery of the king as a sun in the heavens; there are those images belonging to the world of men - the king as gardener tending his kingdom, as helmsman guiding the ship of state, as physician caring for his people, as father watching over his family, as shepherd tending his flock. There is also, echoing the organic analogy of Saint Thomas Aquinas, the image of the king as the head of the body politic with the people as its members. All these images express notions of harmony and order, of a state of being in accordance with both natural and divine law. They all reinforce the idea of the importance of 
a good king for the proper functioning of his kingdom and they convey a sense of the greatness of his moral responsibility.

Erasmus however does more than reproduce classical notions of kingship. His prince is at the same time set apart from all men by his responsibilities and one with them as a man answerable to a Christian God for his actions. In both his Institutio and his earlier Enchiridion Militis Christiani of 1503, Erasmus stresses the need for personal "pietas" in a prince. As a private person he is bound by the same awesome obligations that are incumbent upon all Christians. Before all else he must put his inner house in order, and for Erasmus the notion of kingly responsibility is inseparable from his notion of individual "pietas". A king is "the likeness of God and his vicar" (Institutio, p. 158), is one who "moves in the place of Christ" (Institutio, p. 165), implying a total commitment to a life of personal devotion and service. A king's glory is not to be measured in wordly terms: "Nothing is so becoming, so splendid, so glorious, in kings as to resemble as closely as possible Jesus, the King of all, who just as He was greatest, was also best" (Enchiridion, p. 155) ${ }^{2}$. Such a king will accept that "The model in government is to be taken from God himself and from Christ who was both God and man" (Institutio, p. 183).

When Erasmus, then, writes about a prince he does so from a perspective coloured by his evangelising zeal. ${ }^{3}$ His purpose is always to teach princes, to exhort them, to admonish them when they fall. If a prince is found wanting, the implications for his kingdom are horrendous inasmuch as it is from him that the kingdom derives its moral strength. The prince has no less a task than to maintain in the state an order that is as close as possible to that which existed on earth before sin sowed the seeds of discord and dissonance. In the Enchiridion Erasmus speaks of the disorder created within the individual soul when "the rightful order of things having been disrupted, physical passions try to dictate to reason and reason is compelled to give way before the desires of the body" (p. 64). He pursues this idea, comparing the breast of man

to a sort of factious commonwealth which, consisting of varying classes of men with clashing interests, is bound to be shaken by frequent disturbances and commotions unless one man has the supremacy of power, and unless that man has such character that he imposes only what is conducive to the well-being of the state. (pp. 64-65)

While in a man reason should rule over passion, in a state the prince plays the role of reason and unbridled passions are as "the very dregs of the mob" (p. 65). The choice of a tutor for such a prince is crucial, because "Just as one who poisons the public fountain from which all drink deserves more than one punishment, so he is the most harmful 
who infects the mind of the prince with base ideas, which later produce the destruction of so many men" (Institutio, p. 146). Such a person commits a double murder, destroying a prince by taking away his integrity and thereby also destroying his state.

To express the full magnitude of the implications of corrupt government Erasmus reaches for imagery of a cosmic nature, writing,

No comet, no dreadful power affects the progress of human affairs as the life of the prince grips and transforms the morals and character of his subjects.

(Institutio, p. 157)

And again:

If the celestial bodies are thrown out of order only slightly, or wander from their true course, they do not do it without serious disasters to mankind, as we clearly see manifested in eclipses of the sun and moon. The same is true of great princes. If they wander from the path of honor or do any wrong through ambition, anger or stupidity, they cause a great deal of misfortune to the whole world. (p. 248)

In 1517, when Erasmus in his Querela Pacis expresses his moral outrage at the conduct of Christian monarchs, he further develops the ideas expressed in the Enchiridion and the Institutio. The overall framework of his treatise is clear. The harmonious order of the natural world is disturbed only by man with his warlike propensities. War is both unnatural and sinful, in that it contravenes the sacramental bonds that should bind Christian men together in unity. Any prince who pursues war is contributing in a profound way to a disordered universe. Such a Christian prince is further guilty of abandoning the teachings of Christ, and the Querela Pacis unfolds against a background of eloquent pleading for true personal piety and of righteous indignation at the all too frequent sins of the great. ${ }^{4}$

The major aspects of Erasmus' ideas on kingship are fully elaborated before 1520. While owing much to classical and to mediaeval sources, they are distinctive in this emphasis they place on "pietas" and are the antithesis of a Machiavellian pragmatism that seemed frequently to be the order of the day in sixteenth-century power-politics. Erasmus willingly sets himself up as the conscience of princes and is quite fearless in calling the erring to account.

This willingness to call to account is not shared by Ronsard, whose role during the Wars of Religion is basically not that of a critic of the monarchy but that of a propagandist. ${ }^{5}$ He expresses his ideas in images that come from the same sources as those of Erasmus, he writes didactic passages $^{6}$ that recall the importance attached by Erasmus to the formation of a Christian monarch, and yet the total effect of his work is 
quite un-Erasmian in its impact. It tends in the main towards glorifying the king and towards inspiring in the people a sense of awe at his majesty. Ronsard does not censure kings for failing their subjects in any way - he does not, in fact, envisage the possibility of such a failure. Rather, for whatever personal or propagandising reasons, he chooses to assume that the princes of whom he writes are either young and well on the way to becoming paragons of virtue or at the age of discretion and models of their kind.

Like Erasmus, Ronsard uses imagery having to do with nature and the elements to stress the organic relationship between a prince and his kingdom, but, while in Erasmus the image is always turned towards reminding a prince of his responsibility towards his subjects, in Ronsard the emphasis is upon giving the reader a sense of the grandeur and almost super-human majesty of the prince. We see, for example, how nature responds to and becomes animated by the presence of her prince and takes on voice to praise him. François de France is told by a hamadryad that the woods and forests sing his praises, that all things that are green gladly praise and boast of his honours, so that the river Loire may carry them to the sea; the sea in turn tells them to the winds; from the wind, through the air, they rise to the Heavens. ${ }^{7}$ In "Elegie a la Mageste de la Royne ma maistresse", written in 1564, Catherine de Medicis is assured that for her coming the countryside will appear at is most beautiful and while she is absent it will wear widow's weeds. Says Ronsard,

Si vous venez, vous verrez vos allées
Desouz vos pas d'herbes renouvellées,
Et voz jardins plus verds et plus plaisans
Se rejeunir en la fleur de leur ans;
Ou bien, Madame, ils devriendront steriles,
Sans fleurs, sans fruict, mal plaisans, inutiles,
Et peu vaudra de les bien disposer,
Les bien planter, et bien les arroser:
Le jardinier ne pourra faire croistre
Herbe ne fleur sans voir l'oeil de leur maistre.

(XIII, pp. 145-46, 11.81-89)

All nature celebrates the king's presence and nature herself in turn endows him with her riches. In a series "Mascarades" performed at Bar-le-Duc for Charles IX, the four elements, earth, air, fire and water, in turn address the young king. Earth has given Charles her beauty, stored up for a thousand years; from the sea he receives strength and honour, from the air, mastery:

Pour commander au monde j'ay fait naistre

Ce jeune Roy le plus grand des humains.

(XIII, p. 223, 11.17-18) 
And as for fire,

Ce que j'avois de clair et de gentil,

De prompt, de vif, de parfait, de subtil,

Je l'ay donné à Charles Roy de France.

(11.19-21)

The king, nature, and the elements all fit into a pattern of harmony and purpose. Within this pattern the people are subtly encouraged to admire their king and rejoice at their good fortune.

All this is not to say that in Ronsard due place is not given to the question of a prince's moral responsibility and wisdom. When talking of a king's need for statesmanship Ronsard frequently uses the image of a helmsman, the country being a ship tossed by tempestuous winds, running adrift, the king the wise helmsman guiding the ship safely to haven. ${ }^{8}$ In the "Franciade" in an extremely curious passage, Charles IX is called upon by a god to equip his state with men and vessels, and to cause it to walk on the waves' crest to those places where he is led by destiny. In the "Discours des Misères de ce Temps," Ronsard calls on Catherine de Médicis to rescue the ship of state, battered by hail, rain, seditious winds, and the fury of the heavens, and to guide it to port. ${ }^{10}$

In lines which Erasmus would have found unexceptional, Ronsard writes that a good prince is a mirror reflecting the image of God:

\footnotetext{
Nature qui peult tout, dont le ventre desserre

Toutes perfections, ne donne à nostre terre

Rien si parfaict qu'un Roy modeste et modéré,

Et au poids de vertu justement mesuré.

Seul entre les humains il a peint au visage

De Dieu le venerable et redoutable image:

Il en est le mirouër.
}

(XVIII, pp. 16-17, 11.325-31)

Using the father image, he writes,

Nostre Prince est bon, tres-juste et tres-chrestien,

Qui fera toujours bien s'on le conseille bien,

Seul bon pere et bon Roy de sa France loyale.

(XVIII, p. 104, 11.187-89)

Through his use of sun imagery he conveys a sense of both the glory and majesty of the king and also of his moral function as one who dissipates the forces of darkness. ${ }^{11}$

Perhaps the difference between Erasmus and Ronsard emerges most clearly if we consider their points of view as observers. Ronsard sees the splendour and panoply that surround a king. He describes them in a way that is calculated to capture the attention of the populace, to heighten their sense of admiration and awe for this almost super-human being. 
He draws heavily on analogies with the gods of classical mythology in creating his chosen effects. ${ }^{12}$ In fact he turns far more frequently to classical mythology than to Christian tradition for his imagery. He consciously creates an extremely favourable picture of a succession of noble, worthy, albeit young, kings, surpassing in wisdom and power the rulers of classical antiquity and surpassing also in glory the gods of Greece and of Rome. Erasmus on the other hand sees the richness and ceremony of a king's court but chooses not to describe it at length. His is the attitude of the moral observer. In the Institutio he writes,

The prince should learn to philosophize about those very decorations with which he is adorned. What does the anointing of the king mean, unless the greatest mildness of spirit? What significance has the crown on his head, if not wisdom that is absolute? What is the meaning of the collar of plaited gold around his neck, except the union and harmony of all virtues? What is symbolised by the bright rays of gems shining with many colors, if not the highest degree of virtue and that whatever is honorable ought to be found in a special degree in the prince? What does the rich purple mean, except an ardent love toward his subjects? What do his various decorations mean, except that he should either equal or exceed the glorious deeds of his ancestors? What is the significance of the sword that is carried before him, unless that his country ought to be safe under the protection of this man, safe both from outside enemies and those within.

(Institutio, p. 187)

While in his "Institution pour l'Adolescence du Roy Tres-Chrestien Charles IX de ce nom" Ronsard counsels moderation in dress -

Ne vous monstrés jamais pompeusement vestu,

L'habillement des Roys est la seule vertu:

Que votre corps reluise en vertus glorieuses,

Et non pas vos habits de perles precieuses.

(XI, p. 12, 11.163-66)

- the totality of his work gives an image of kingly majesty and pomp beautifully evoked in the opening lines of a madrigal to Henri III:

Perles, rubis et pierres precieuses

Soient pour le front de ce royal guerrier,

Prince invincible. ...

$$
\text { (XVII, p. 339, 11.1-3) }
$$

What Erasmus sees most frequently is the omnipresent danger of corruption, the need for a king constantly to be on guard, to strive to be a truly Christian ruler. We are constantly aware in his work both of the difficulty of the task and of the extent to which contemporary rulers frequently fall short of it. Erasmus is the conscience of Europe, Ronsard the propagandist of the French monarchy in the most perilous of times. 
Just as Ronsard, the propagandist, cannot touch on any possible flaws in the royal princes of France, so too, when he writes of France as a kingdom he does not for a moment explore the possibility of its problems being due, in any small measure, to its rulers' wisdom, or lack of it. The country may alternate between brief periods of peace and the miseries of civil war, but the image of the good king is constant, his credit intact.

When writing of the country at peace, Ronsard frequently turns to the classical notion of a golden age, with all its fruitfulness, abundance and pastoral tranquillity. ${ }^{13}$ At one point he credits Henri II with the fact that

Par toy l'Abondance ayant pleine

Sa riche corne jusque aux bordz,

A doré la Françoise plaine.

$$
\text { (III, p. 91, 11.19-21) }
$$

In a "Bergerie," written probably for a performance at Fontainebleau in the spring of 1564, the young Henri de Guise tells Charles IX that, when he is grown "homme entier et parfait," wars will cease and everything connected with the old age of Iron will flee, giving way to the age of Gold. Manna will fall on fields, which will of themselves bring forth grain. Sickle and pruning-knife will be laid aside and Nature will work her own wonders:

Le miel distilera de l'escorce des chesnes,

Et les roses croistront sur les branches des fresnes:

Le belier, en paissant au millieu d'un pré vert

Se voirra tout le dos d'escarlate couvert,

De pourpre l'aignelet et la barbe des chevres

En soye deviendra pendante souz leurs levres,

Les cornes des toreaux de perles, et encor

Le rude poil des boucs jaunira de fin or.

Bref tout sera changé, et le monde, difforme

Des vices du jourd'huy, prendra nouvelle forme

Desouz toy qui croistras pour avoir ce bon heur,

O Prince bien heureux, d'estre son gouverneur.

(XIII, pp. 109-10, 11.671-82)

Within this context of a golden age Ronsard stresses the almost miraculous powers of the king, who seems to set in motion a period in which nature, surpassing herself, is transformed into "something rich and strange." Unfortunately the realities of contemporary politics make it impossible to dwell upon this vision and the scene changes dramatically when Ronsard writes of the horrors of civil war. In the "Bocage Royal" the seas of France are paved with broken vessels, her plains strewn with bones; the carnage of the battle of Moncontour is described in graphic 
terms; in a poem written after the battle of Moncontour and aptly entitled "Les Elemens Ennemis de l'Hydre" the Protestants are transformed into a hydra-headed monster; elsewhere Protestants are shown as locusts of the Apocalypse, as vipers whose abortive birth causes the death of France, the mother, as caterpillars nestling in an apple tree throughout the winter who, when they are warmed by the sun's rays, become active and ultimately infect the whole orchard; because of them ploughshares are bent into swords, order is overthrown, discord reigns. ${ }^{14}$ The country then is infected but not at its heart. In the "Bocage Royal" the ship of state will still respond to the touch of her helmsman; the horror of Moncontour turns into a triumph for Henri III and the images of disaster give way to that of Henri as a glorious sun before whose brightness the shadows of civil war will flee - the light of day banishing the darkness of false belief; and in "Les Elemens Ennemis de l'Hydre" all the elements are to join in waging war against the monster, whose body shall finally be rejected by Earth itself. ${ }^{15}$ Throughout this disastrous period the king's influence is seen as a healing one, and his merits and triumphs celebrated in verses replete with the most flattering comparisons to the great conquerors, real or mythical, of classical antiquity. ${ }^{16}$ Ronsard's king is not an Erasmian-style monarch, struggling at one and the same time to realise within himself the Christian concept of "pietas" and to be guided by it in ruling his kingdom. He is the shining knight, the Hercules, the strong man fighting against the powers of darkness given visible shape in the person of the Protestants. ${ }^{17}$ His demons are outside himself and in conquering them he achieves almost supernatural proportions. At the risk of establishing too neat a dichotomy, it might be argued that Erasmus and Ronsard both reflect the classical tradition in much of their imagery, but that Erasmus sets very clear Christian limits to a king's worldly glory and ambition, while Ronsard uses the full range of classical tradition and mythology to paint his picture of a king as demi-god.

Not so with Agrippa d'Aubigné. Turning to his work, and principally to Les Tragiques, ${ }^{18}$ we are given a picture of the Wars of Religion and of the kings of the period that is dramatically different from that drawn by Ronsard. It would seem at first glance as though d'Aubigné, in fact, had very little in common with either Erasmus or Ronsard. From Erasmus he is separated in time by almost a century; from Ronsard, he is separated ideologically by the chasm which divided Catholic from Protestant in late sixteenth-century France. In fact, it is possible to establish areas of communality with both.

As with Erasmus and Ronsard, the philosophical framework of d'Aubigné's imagery is to some extent classical, but whereas the former develop for the most part positive images that reinforce an ideal view of 
the relationship between king and state, d'Aubigné emphasises the profound dislocation that occurs on a moral, social and even physical level when a king falls short of his God-given task. To express his sense of outrage and deep sorrow at the cataclysmic events of the Wars of Religion, d'Aubigne frequently creates pictures that are directly contrary to those of Ronsard. His images are those of death as opposed to life, of corruption as opposed to health. The Catherine de Medicis of the "Elegie à la Magesté de la Royne," by her presence, calls the countryside into more abundant life, by her absence condemns it to sterility. In d'Aubigné the reverse is true; it is in Catherine's presence that flowers die, because

C'est la peste de l'air, l'Erynne envenimee,

Elle infecte le ciel par la noire fumee

Qui sort de ses nareaux; ell' haleine les fleurs:

Les fleurs perdent d'un coup la vie et les couleurs.

("Misères," p. 42, 11.889-92)

Again, where Ronsard showed the same Catherine calming the elements, in d'Aubigné she stirs them up into fury changing the earth to ashes and water to blood. ${ }^{19}$ In Ronsard the elements joined in celebrating the endowments of Charles IX. In d'Aubigné the elements rise up against the princes of France:

les beautés de Nature,

Que leur rage troubla de venim et d'ordure,

Se confrontent en mire et se levent contr'eux.

("Jugement," p. 233, 11.767-69)

Fire complains that she was misused in the burning of Protestants; Air rails against being polluted, poisoned with "charognes, de pestes, des corps de vos meurtris" (11.776-77); Water laments that the silver of her streams ran red with blood; Earth complains that her children were buried alive in her womb. ${ }^{20}$ D'Aubigné too reshapes the image of the king as father of his people and shepherd of his flock and makes of it an image of destruction:

Les Rois, qui sont du peuple et les Rois et les peres,

Du troupeau domesticq sont les loups sanguinaires.

("Misères," p. 25, 11. 197-98)

The father/shepherd is himself the wolf, who sucks blood from the sheep through a hole in the stomach, leaving in his wake a flock outwardly intact but in fact dead. ${ }^{21}$ D'Aubigné's king is not an eagle but a falcon, and one furthermore that does not fly towards its designated prey. When his princes are shown as lions, they appear as lions held at bay by torches or as devouring beasts with no trace of nobility. ${ }^{22}$ Kings, in d'Aubigné's world, are scavengers, birds of prey, travesties of royal 
dignity, courage and honour. His world is "out of joint," the unnatural rules as the rulers themselves go against nature.

Both Ronsard and d'Aubigné have a vision of Paradise, but, while Ronsard sings of the restoration of a Golden Age under charmed rulers, d'Aubigné relegates any such dreams firmly to the past:

Ces ruisselets d'argent, que les Grecs nous feignoyent

Où leurs poëtes vains beuvoyent et se baignoyent,

$\mathrm{Ne}$ courent plus ici; mais les ondes si claires

Qui eurent les sapphirs et les perles contraires

Sont rouges de nos morts; le doux bruit de leurs flots,

Leur murmure plaisant heurte contre des os.

("Misères," p. 22, 11.59-64)

The streams of France are filled with bones; the land has turned to ashes. France is again personified, as she was in Ronsard, but now the various forms she takes on all serve to stress her barrenness, desolation and suffering. She is a mother torn in two by children who quarrel at her breast; her towns are full of corpses, as sheep killed by wolf, their vital juices drained away. ${ }^{23}$ One of her cities, which in happier days was decked out to celebrate the entry of a prince, is now depicted as an exhausted body over which a tyrant struts, a woman's body, with no milk in her breasts:

Quand le tyran s'esgaye en la ville où il entre,

La ville est un corps mort, il passe sur son ventre,

Et ce n'est plus du laict qu'elle prodigue en l'air,

C'est du sang....

$$
\text { ("Misères," p. 35, 11.585-88) }
$$

For d'Aubigné there will be no restoration of a Golden Age on earth but rather a just retribution for sinners and recompense for the blessed in Heaven. His paradise is a heavenly one, his just monarch the King of Kings. In spirit d'Aubigné is in fact very close to Erasmus. When Erasmus wishes to present the portrait of an ideal king who restores and maintains in the world an order that is in accordance with the will of God, he uses images that stress good stewardship and harmony. To draw a portrait of a tyrant, as d'Aubigné does later, he uses images that are the reverse of the former - darkness not light, a ravaging wolf rather than a good shepherd, cosmic disorder in place of harmony. In the Institutio, writing against capital punishment, Erasmus states,

A reliable and skilled physician never resorts to an operation or cauterizes if he can stop the malady by plasters and strong medecines; and he never resorts even to those unless forced to do so by (the seriousness of) the disease. So a prince should try every remedy before resorting to 
capital punishment, keeping in mind that the state is a single body. Noone cuts off a limb if (the patient) can be restored to health by any other means. The honest physician has only one purpose in mind when he prepares his remedies and that is how to overcome the ailment with the very least danger to the patient; so it is with the good prince in passing laws. He has no other end in view than the advantage of his people and the remedying of their misfortunes with the least disturbance.

(Institutio, pp. 224-25)

The image reappears in Les Tragiques, only this time the physician himself is sick and does indeed perform acts contrary to his basic function. The king is head of his people and such a head is filled with madness when it does not conserve its blood, its life; a head is no longer truly a head when it takes pleasure in cutting away arms and legs from its body. If a limb is gangrenous, to amputate it will save the body, but in this instance it is the brain that must be purged:

Que le cerveau se purge, et sente que de soy

Coule du mal au corps auquel il est roy.

$$
\text { ("Princes," p. 65, 11.483-84) }
$$

Unhappily, the manic surgeon is not one to operate on himself!

D'Aubigné's kings lack "pietas," and this being the case they can never be beneficent influences. Their own moral corruption is symbolised by the pus that rises to their eyes and hides truth from them; by their actions they then spread their venom through the land. ${ }^{24}$ To describe them d'Aubigné reaches for images ever more baroque in their extravagance and frequently produces passages that bear a remarkable resemblance to some found in Erasmus. In both, the underlying notion is that sin hideously deforms whatever it inhabits. In the Institutio Erasmus, having advised the prince's tutor on how to depict the qualities of a good prince, continues as follows:

Now let him bring out the opposite side by showing a frightful, loathsome beast, formed of a dragon, wolf, lion, viper, bear, and like creatures; with six hundred eyes all over it, teeth everywhere, fearful from all angles, and with hooked claws; with never satiated hunger, fattening on human vitals, and reeking with human blood; never sleeping, but always threatening the fortunes and lives of all men; dangerous to everyone, especially to the good; a sort of fatal scourge to the whole world, on which everyone who has the interests of state at heart pours forth execration and hatred; which cannot be borne because of its monstrousness and yet cannot be overthrown without great disaster to the city because its maliciousness is hedged about with armed forces and wealth. This is the picture of a tyrant - unless there is something more odious which can be depicted.

(Institutio, p. 163) 
He elaborates further:

If you want a comparison for the tyrant, take the lion, bear, wolf, or eagle, all of which live on their mangled prey. Since they know they are open to the hatred of everyone and are beset with ambuscades all around them, they dwell on rugged cliffs, or hide away in caverns and desolate regions - unless perchance the tyrant exceeds the savageness even of these beasts.

$$
\text { (op. cit., p. 166) }
$$

D'Aubigné uses these desolate places as an image of the tyrant, peopling them with all the monsters of Erasmus' imagination - and more besides - and in one bravura passage that unites in wild extravagance all kinds of nature and body imagery draws an unforgettable picture of corrupted monarchy:

Les monts les plus hautains, qui de rochers hideux

Fendent l'air et la nue et voisinent des cieux,

Sont couverts de neige, et leurs cimes cornuës

Des malices de l'air, des excrements des nuës

Portent le froid chappeau; leurs chefs tous fiers et hauts

Sont braves et fascheux, et steriles et beaux;

Leur coeur et leur milieu on oit bruire des rages

Des tigres, des lions, et des bestes sauvages,

Et de leurs pieds hideux aux rochers crevassez

Sifflent les tortillons des aspics enlassez;

Ainsi les chefs des grands sont faits par les malices

Steriles, sans raison, couverts d'ire et de vices,

Superbes, sans esprit, et leurs seins et leurs coeurs

Sont tigres impuissans et lyons devoreurs,

En leurs faux estomacs sont les noires tasnieres,

Dans ce creux les desirs, comme des bestes fieres,

Desirs, dis-je, sanglants, grondent en devorant

Ce que l'esprit volage a ravi en courant;

Leurs pas sont venimeux, et leur puissance impure

N'a soustien que le fer, que poison et qu'injure;

Dans ce superbe mont les serpents sont au bas,

La ruse du serpent conserve leurs estats,

Et le poison secret va destruisant la vie

Qui, brave, s'opposait contre la tyrannie.

("Princes," pp. 62-63, 11.367-90)

At times the very specificity of d'Aubigné's descriptions tend to make one lose sight of the tradition within which he works. In Erasmus, in Etienne Pasquier, in all good humanist thinkers, the country is represented as a body, the king as its head. So too in d'Aubigné, but with him the traditional view is expressed with fresh vigour and a deep and abiding anger. In one memorable instance France is seen as a giant who in his pride challenges the heavens to combat but who is reduced to turning on himself. Phlegm and anger change the nature of his blood, 


\section{8 / Renaissance and Reformation}

the body rots, fills with dropsy; the stomach bloats, there is no marrow in the bones, the brain nourished by a poisonous bile takes on the consistency of a rotten mushroom. Atop this immense, grotesque body sits a small head, at its sides hang two feeble, dried-up, lifeless arms; its legs are powerless, incapable of supporting this heavy, suppurating mass. ${ }^{25}$

Philosophically Erasmus, Ronsard and d'Aubigné all have the same ideal of what a good king should be, and they express this ideal in images drawn from a rich classical and Christian tradition. One is of course struck by the enormous, and expected, difference in perspective between Ronsard and d'Aubigné. The king-monsters of Les Tragiques are the demi-gods of Ronsard's poetry. Where in Ronsard they heal, in d'Aubigné they deal death. While in Ronsard they are compared with the proud conquerors of antiquity or heroes of classical mythology, in d'Aubigné they appear as a Nero, a Jezebel or a Nabuchodnosor. ${ }^{26}$ In Ronsard France's kings struggle to save Catholic France in the name of true religion; in d'Aubigné Protestants are martyrs, the pope appears as Antichrist and the same kings do the work of the devil. However, although both poets obviously propagandise, they uphold the same Christian humanist notions of kingship. ${ }^{27}$ Moreover d'Aubigné, at the end of the sixteenth century, provides a striking parallel with Erasmus. It is in him that we catch again the evangelizing zeal of Erasmus, his deep moral conviction, his capacity for honest outrage and his willingness to call the great to account. The most distinctive and personal of Erasmus' contributions to theories of kingship find their echo throughout Les Tragiques. It is a measure of their vigour that they can reappear in so seemingly unlikely a context.

\section{York University}

Notes

1 All quotations from the Institutio principis Christiani are taken from The Education of a Christian Prince, by Desiderius Erasmus, trans. Lester K. Born (New York: Octagon Books Inc., 1965). The introduction contains a comprehensive survey of ideas of kingship in the classical and mediaeval periods.

2 All quotations from the Enchiridion Militis Christiani are taken from The Enchiridion of Erasmus, trans. and edit. Raymond Himelick (Bloomington: Indiana University Press, 1963).

3 For a further analysis of this point, see Pierre Mesnard, L'essor de la philosophie politique au seizième siècle, 3 ed., Librairie philosophique (Paris: J. Vrin 1969), pp. 91-92, pp. 136-37.

4 For an examination of circumstances under which war may be justified, see José A. Fernandez, "Erasmus on the Just War," Journal of the History of Ideas, 34 (1973), n.2, pp. 209-26.

5 All references to Ronsard's work are from Pierre de Ronsard: Oeuvres Complètes, edit. Paul Laumonier (Paris, 1914-1967). 
6 Ronsard, XI, pp. 3-13, 11.1-186; XIII, pp. 126-30, 11.997-1084; XVII, p. 342, 11.9-14.

7 XVII, pp. 343-44, 11.1-11.

8 VII, pp. 6-7, 11.9-29; XII, p. 173, 11.9-13; XVII, p. 26, 11.145-56; XVIII, p.5, 11.85-88; p. $104,11.176-84$.

9 XVI, p. 48, 11.377-82.

$10 \mathrm{XI}$, p. $21,11.43-50$.

11 XV, pp. 349-51, 11.1-48; XVI, p. 48, 11.379-81; XVII, pp. 345-46, 11.5-8.

12 VIII, p. 24, 11.359-68; XII, pp. 292-3, 11.1-14; XIV, p. 121, 11.9-10; pp. 133-34, 11.1-8; p. $137,11.62-66$; XV, p. $348,11.31-42$; XVII, p. $345,11.1-4 ;$ p. $346,1.11$.

13 See also Elizabeth Armstrong, Ronsard and the Age of Gold (London: Cambridge University Press, 1968), pp. 37-42, for a further analysis of the theme of the Golden Age in Ronsard's Elegies, Mascarades et Bergerie, 1565.

14 XVIII, p. 3, 11.44-46; XVII, p. 21, 11.60-76; pp. 408-11, 11.1-74; XI, p. 39, 11.71-76;p. 40, 11.91-94; pp. 55-56, 11.351-64; p. 28, 11.172-75.

15 XVII, p. 21, 11.43-50; p. 25, 11.123-30; pp. 410-11, 11.51-66.

16 VIII, pp. 9-10, 11.79-102; XV, pp. 61-66, 11.1-108; XVIII, pp. 15-16, 11.291-324.

17 For an analysis of Ronsard's use of the Herculean image, see Marc-René Jung, Hercule dans la littérature française du seizième siècle, Travaux d'Humanisme et Renaissance, 79 (Geneva: Droz, 1966), pp. 164-67.

18 All references to d'Aubigné's work are from d'Aubigné, Oeuvres, edit. Henri Weber, Bibliothèque de la Pléiade (Paris: Gallimard, 1969).

19 "Misères," p. 42, 11.895-98. For an analysis of the demonic power attributed to Catherine de Medicis, see Jacques Bailbé, Agrippa d'Aubigné, poète des Tragiques (Caen 1968), pp. 241 42; Marguerite Soulié, L'inspiration biblique dans la poésie religieuse d'Agrippa d'Aubigné (Paris: Klincksieck, 1977), pp. 242-44.

20 "Jugement," p. 233, 11.770-94.

21 “Misères," p. 35, 11.601-04; cf. Bailbé, p. 385.

22 “Princes," p. 77, 11.987-92; “Jugement," p. 233, 1.765.

23 "Misères," p. 23, 11.97-110; p. 35, 11.605-06.

24 "Princes," p. 57, 11.152-53.

25 "Misères," pp. 24-25, 11.131-62.

26 “Misères," p. 40, 11.813-14; p. 38, 1.745.

27 See also Bailbé, pp. 335-40. In fact even the Saint Bartholomew's massacre does not serve to call in to question notions of kingship as distinct from notions of the worthiness, or otherwise, of individual kings; see Michel Reulos, "La Saint-Barthélemy; thème politique ou thème religieux," Revue d'histoire littéraire de la France, 73 (1973), n.5, pp. 778-83. 